\title{
GAS NATURE EFFECT ON THE DESTRUCTION OF VARIOUS MICROORGANISMS UNDER CAVITATION ACTION
}

\author{
Iryna Koval ${ }^{1,}{ }^{\otimes}$, Volodymyr Starchevskyy ${ }^{1}$
}

https://doi.org/10.23939/chcht14.02.264

\begin{abstract}
The disinfection of water from Diplococcus, S.lutea, B.cereus, and Ps.fluorescens bacteria types and the yeast Sacch.cerevisiae via the joint action of gas/US has been investigated. The investigated microorganisms were identified in natural water and wastewater in dominant amounts. The relative ranges of effective cell destruction by combined gas/US action have been established. The most efficient microorganism destruction has been obtained using Ar/US compared to $\mathrm{He} / \mathrm{US}$, $\mathrm{CO}_{2} / \mathrm{US}$ and $\mathrm{O}_{2} / \mathrm{US}$ and is accounted for by those gas properties able to affect sonochemical activity.
\end{abstract}

Keywords: cavitation, gas, water, microorganism, destruction.

\section{Introduction}

One of the most important tasks in water treatment technology is the development of methods which exclude chemical reagent usage such as chlorine or ozone, for the latter lead to the formation of toxic compounds $[1,2]$. Recently researchers have turned their attention to physical methods of water treatment, especially the use of acoustic cavitation via ultrasound (US). Water disinfection under the influence of cavitation is supported by many research studies [3-8]. Acoustic cavitation is the phenomenon by which intense ultrasonic waves induce the formation, growth and subsequent collapse of dynamic microbubbles in a liquid [9].

The actions of cavitation alone, of bubbling gas alone and of the simultaneous action of cavitation and gas bubbling upon the disinfection of sewage water, natural water and microbial dispersions were considered in our previous study [10-12]. We observed that sonication enhanced the breakup of floc caused by microorganisms clumping together, which made them more susceptible to disinfection [11]. A mathematical model for the gas (Ar, $\mathrm{He}, \mathrm{O}_{2}$ ) effect on the process of water purification from Bacillus bacteria type in the absence of cavitation was proposed [13]. Our investigations showed that the

\footnotetext{
${ }^{1}$ Lviv Polytechnic National University,

12, Bandera St., 79013 Lviv, Ukraine

irynazk@gmail.com

(c) Koval I., Starchevskyy V., 2020
}

efficiency of microorganism destruction under the influence of cavitation was explained by cell membrane destruction induced by cavitation. A considerable number of studies were concentrated on the influence of cavitation on Escherichia coli cells, as traditionally they are the testorganisms used to evaluate the microbiological decontamination of water $[1,4-6,8]$. The effect of cavitation on the removal of fungi, Enterococcus avium and algae of Microcystis aeruginosa, cyanobacteria has also been presented [8, 14-17]. However, information on the cavitation effect on a wider range of various microorganisms is limited. The effect of cavitation is used not only for technological purposes, but also in the chemical industry, in particular in the process of modifying road bitumen [18], oxidation processes [19], etc.

The purpose of current investigation is to study the action of cavitation in the presence of different bubbled gases (Ar, $\mathrm{He}, \mathrm{CO}_{2}, \mathrm{O}_{2}$ ) on the viability of Diplococcus, Sarcina lutea, Bacillus cereus, Pseudomonas fluorescens bacteria and the yeast (Saccharomyces cerevisiae) in aqueous media. The study of the different gases effect in a cavitation field, as well as the study of the behavior of a given gas in a cavitation field may help to determine the most efficient disinfection conditions for a range of microorganisms with different structural features.

\section{Experimental}

The investigated aqueous media were model dispersions prepared from natural water with added pure microorganism monocultures (Diplococcus, Sarcina lutea, Bacillus cereus, Pseudomonas fluorescens bacteria types and the Saccharomyces cerevisiae yeast). Thereby, five model dispersions containing different microorganisms were investigated.

The pure microorganism cultures were grown in test tubes in laboratory conditions at $310 \mathrm{~K}$ for $48 \mathrm{~h}$ (for bacterial cells) and at $303 \mathrm{~K}$ for $96 \mathrm{~h}$ (for yeast cells), on an agar nutrient medium with subsequent storage at $277 \mathrm{~K}$. The agar nutrient medium composition is given below.

In our opinion, to simulate water disinfection under acoustic cavitation conditions, the microorganisms used in such studies need to be those most typically found in 
natural and sewage water. For this purpose, identification of microorganisms in different water sources was carried out (Table 1). So, in this study we investigated the effect of gas/US action on microorganisms that were previously identified in variously contaminated water sources. The qualitative microorganism composition of these water sources is also presented in Table 1.

Microorganisms in water sources under investigation were investigated by microscopy (coloration by Gram, cell sizes) to determine cell morphology. Their physiological (response to oxygen after being injected in a solid substrate in a test tube and response during growth in a nutrient medium) and culture features (the nature of colony growth on a nutrient medium in Petri dishes: colony form and profile, size, color, surface, shine and transparency, structure and consistency, edges; colony growth characteristics on the cross-hatched surface of test tube substrate: growth intensity, cross hatch features, color and surface) were investigated as well (Tables 2 and 3).

"Crushed drop" preparations with Lugol solution as a coloring agent and fixed cells preparations with safranin as a coloring agent were used to study the morphological features of the cells. "Crushed drop" preparation involved the evaluation of water samples with the aid of a microscope.

The source of cavitation was an ultrasonic wave source, namely UZDN-2T generator operating at the frequency of $22 \mathrm{kHz}$ generating $35 \mathrm{~W}$. Ultrasonic vibrations were transmitted by the magnetostriction radiator, which was immersed in the water being studied. During the investigations, the glass reactor vessel containing the dispersions $\left(V=75 \mathrm{~cm}^{3}\right)$ was cooled throughout the process with tap water.

All experiments were carried out at $T=298 \pm 1 \mathrm{~K}$, $P=0.1 \mathrm{MPa}$, and process time $t=2 \mathrm{~h}$. Our previous studies showed that in the absence of US/gas, microorganisms quantity did not vary over a two-hour period in all water sources under investigation.

The degree of microorganism destruction $\left(D_{d}\right)$ after gas/US treatment was found to be equal to the number of microorganisms $(N M)$ at any given time relative to the initial number of microorganisms $\left(N M_{0}\right)$ expressed as a percentage.

The effects of various gases such as oxygen, argon, helium, and carbon dioxide were comparatively investigated. Throughout the entire process gases were bubbled at the rate of $\sim 1 \mathrm{~cm}^{3} / \mathrm{s}$ into the water under investigation. Gas bubbling and sonication were applied simultaneously to the glass reactor vessel.

Samples of sonicated water $\left(1 \mathrm{~cm}^{3}\right)$ were poured onto the nutrient medium in Petri dishes: meat water $\left(1 \mathrm{dm}^{3}\right)$, peptone $(10 \mathrm{~g})$, agar $(15 \mathrm{~g})$ for bacteria and a malty mash $\left(1 \mathrm{dm}^{3}\right)$ containing solids $(6-8 \%)$ and agar ( $2 \%)$ for the yeast. Petri dishes were placed in a TS-80M-3 thermostat at $310 \mathrm{~K}$ for $48 \mathrm{~h}$ (for bacterial cells) and at $303 \mathrm{~K}$ for $96 \mathrm{~h}$ (for yeast cells). Water samples withdrawn before cavitation action were used as reference ones. The concentration of microbial cells was determined by the number of colony forming units (CFU), assuming that each colony developed from a single cell.

\section{Results and Discussion}

In order the qualitative content of the model microorganism dispersions is approached the actual content of microorganisms in contaminated waters, we investigated natural and waste waters (Table 1). Thus, bacteria Sarcina, Diplococcus, Pseudomonas, Bacillus and the yeast Saccharomyces cerevisiae were revealed and subjected to this study. The difference in their morphological, physiological [20] and culture [21] features is significant during the analysis of cell destruction in an aqueous medium (Tables 2 and 3).

Colony culture and cell morphology features are shown in Fig. 1: colony growth characteristics in Petri dishes on a nutrient medium (Ia-Va); fixed bacterial cells preparation with safranin as a coloring agent (Ib-IVb) and "crushed drop" preparation with Lugol solution as a coloring agent for yeast cells (Vb).

Natural water No1 was used for further investigations, as much as the simultaneous action of gas/US on the disinfection of waste and natural waters was presented in our previous work [13].

Depending on aqueous medium conditions and water sampling, the $N M$ dynamics was established based upon a wide range of microbiological studies. Natural water No1 was sampled periodically during June and July. Some insignificant $N M$ variations were observed for 10 days, within the narrow range from 820 to $1080 \mathrm{CFU} / \mathrm{cm}^{3}$, under relatively stable weather conditions, $T_{\mathrm{H} 2 \mathrm{O}}=$ $=286 \pm 2 \mathrm{~K}$. A sharp increase in water source temperature to $294 \pm 1 \mathrm{~K}$ caused a rapid increase of $N M$ (up to $2090 \mathrm{CFU} / \mathrm{cm}^{3}$ ) for a short time, but over next two weeks there was practically no change in $N M$ (Fig. 2).

As a result, natural water No1, with minimum $N M_{0}$ $\left(820 \mathrm{CFU} / \mathrm{cm}^{3}\right)$, was additionally infected by Diplococcus, S.lutea, B. cereus, Ps. fluorescens bacteria types and the Sacch. cerevisiae yeast, i.e. an individual model dispersion was created for each microorganism type. The results of gas/US action on these dispersions are given below.

The experimental results about the effect of acoustic destruction upon microorganisms increase the possibility of water disinfection by gas/US and the possibility of establishing the most effective conditions under which this process will lead to a high degree of microorganism destruction. 
Table 1

Microorganisms detected in the water objects

\begin{tabular}{|c|c|c|}
\hline Investigated water objects & $N M_{0}, \mathrm{CFU} / \mathrm{cm}^{3}$ & Identified microorganisms \\
\hline Natural water No1 & $820-2090$ & Bacterium, Sarcina, Bacillus $*(35 \%)$, Pseudomonas \\
\hline Natural water No2 & $2200-2340$ & Staphylococcus, Pseudomonas, Bacillus $*(40 \%)$ \\
\hline Natural water No3 & $1800-2050$ & Micrococcus, Sarcina Streptococcus, Bacterium* $(29 \%)$, Bacillus $*(32 \%)$ \\
\hline Wastewater No1 & 110000 & $\begin{array}{c}\text { Micrococcus, Sarcina, Bacterium, Pseudomonas } \\
\text { Bacillus } *(25 \%), \text { Saccharomyces }\end{array}$ \\
\hline Wastewater No2 & 38600 & Micrococcus, Diplococcus, Streptococcus, Sarcina, Bacterium, Bacillus $*(22 \%)$ \\
\hline
\end{tabular}

Note: * dominant amounts.

Table 2

Morphological and physiological features of microorganisms

\begin{tabular}{|c|c|c|c|c|c|}
\hline \multirow{3}{*}{$\begin{array}{l}\text { Investigated } \\
\text { microobjects }\end{array}$} & \multicolumn{3}{|c|}{ Morphological features } & \multirow{2}{*}{\multicolumn{2}{|c|}{$\begin{array}{c}\text { Physiological features } \\
\text { Response to oxygen (the intensity of growth) }\end{array}$}} \\
\hline & \multirow{2}{*}{$\begin{array}{l}\text { Coloration } \\
\text { by Gram }\end{array}$} & \multicolumn{2}{|c|}{ Sizes } & & \\
\hline & & $\begin{array}{l}\text { Width, } \\
\mu \mathrm{m}\end{array}$ & $\begin{array}{l}\text { Length, } \\
\mu \mathrm{m}\end{array}$ & $\begin{array}{l}\text { After being injected in a } \\
\text { solid substrate in a test tube }\end{array}$ & $\begin{array}{l}\text { After being injected in a melted substrate in a } \\
\text { test tube }\end{array}$ \\
\hline Bacillus cereus & Gram + & 1.3 & 3.42 & $\begin{array}{l}\text { The superficial thin layer } \\
\text { was created. } \\
\text { Superficial layer: all-round, } \\
\text { dense, wrinkled, plicate. } \\
\text { Isolated colonies in the deep } \\
\text { of medium along the } \\
\text { injection were revealed. }\end{array}$ & $\begin{array}{l}\text { Evenly distributed superficial thin layer of } \\
\text { colonies was found. } \\
\text { Superficial layer is the same as in the case of } \\
\text { solid medium. } \\
\text { Growth of single colonies over the medium } \\
\text { and distributed on the wall of the tube was } \\
\text { revealed. Moderate growth of colonies along } \\
\text { the depth of medium in vitro was revealed. }\end{array}$ \\
\hline Diplococcus & Gram + & 0.6 & - & $\begin{array}{l}\text { The superficial thin layer } \\
\text { was present. } \\
\text { Superficial layer: all-round, } \\
\text { dense, smooth. }\end{array}$ & $\begin{array}{l}\text { Evenly distributed superficial thin layer was } \\
\text { investigated. } \\
\text { Superficial layer is the same as in the case of } \\
\text { solid medium. } \\
\text { Explicit growth of colonies distributed on the } \\
\text { tube wall over the medium. }\end{array}$ \\
\hline Sarcina lutea & Gram + & 2.2 & - & The same & The same \\
\hline $\begin{array}{l}\text { Pseudomonas } \\
\text { fluorescens }\end{array}$ & Gram - & 0.53 & 1 & $\begin{array}{l}\text { Surface growth of the } \\
\text { colonies and intensive } \\
\text { colonies growth along the } \\
\text { injected medium in vitro } \\
\text { was shown. } \\
\text { Superficial layer: all-round, } \\
\text { dense, smooth. }\end{array}$ & $\begin{array}{l}\text { The superficial thin layer was evenly } \\
\text { distributed on the medium surface. } \\
\text { Superficial layer is the same as in the case of } \\
\text { solid medium. } \\
\text { Growth of single colonies on the wall of the } \\
\text { tube over the environment was found. } \\
\text { Intensive colonies growth throughout the } \\
\text { medium depth in vitro was present. }\end{array}$ \\
\hline $\begin{array}{c}\text { Saccharomyces } \\
\text { cerevisiae }\end{array}$ & Gram + & 5.17 & 8.67 & $\begin{array}{l}\text { Superficial layer: } \\
\text { discontinuous, but thick and } \\
\text { dense. Convex colonies } \\
\text { growing upwards. }\end{array}$ & $\begin{array}{l}\text { The superficial thin layer was unevenly } \\
\text { distributed and relatively thick. } \\
\text { Growth of single colonies above medium was } \\
\text { a little distributed on the wall of the tube. }\end{array}$ \\
\hline
\end{tabular}

Table 3

\section{Cultural features of microorganisms}

\begin{tabular}{|c|c|c|c|c|c|c|c|}
\hline \multirow[b]{2}{*}{$\begin{array}{l}\text { Investigated } \\
\text { microobjects }\end{array}$} & \multicolumn{7}{|c|}{ Characteristics of colony growth on a nutrient medium in Petri dishes } \\
\hline & Shape and profile & $\begin{array}{l}\text { Size, } \\
\text { mm }\end{array}$ & Color & Surface & $\begin{array}{l}\text { Shine and } \\
\text { transparency }\end{array}$ & $\begin{array}{l}\text { Structure and } \\
\text { consistency }\end{array}$ & Edges \\
\hline 1 & 2 & 3 & 4 & 5 & 6 & 7 & 8 \\
\hline $\begin{array}{l}\text { Bacillus } \\
\text { cereus }\end{array}$ & $\begin{array}{l}\text { compact, fold, } \\
\text { hilly; } \\
\text { curved profile }\end{array}$ & $\begin{array}{l}<1 ; \\
1-4\end{array}$ & white & $\begin{array}{l}\text { wrinkled } \\
\text { with folded } \\
\text { center }\end{array}$ & $\begin{array}{l}\text { opaque, matt, } \\
\text { moisture }\end{array}$ & $\begin{array}{l}\text { finely granular } \\
\text { (farinaceous); } \\
\text { mucous texture }\end{array}$ & $\begin{array}{l}\text { wavy, } \\
\text { winding }\end{array}$ \\
\hline Diplococcus & $\begin{array}{l}\text { compact, round; } \\
\text { convex or flat } \\
\text { profile }\end{array}$ & $\begin{array}{l}<1 \\
1-3\end{array}$ & $\begin{array}{l}\text { peachy; produce } \\
\text { orange pigment }\end{array}$ & smooth & $\begin{array}{l}\text { opaque, } \\
\text { brilliant, } \\
\text { moisture }\end{array}$ & $\begin{array}{l}\text { homogeneous; } \\
\text { soft texture }\end{array}$ & $\begin{array}{l}\text { smooth, } \\
\text { flat }\end{array}$ \\
\hline
\end{tabular}


Table 3 (continued)

\begin{tabular}{|c|c|c|c|c|c|c|c|}
\hline 1 & 2 & 3 & 4 & 5 & 6 & 7 \\
\hline $\begin{array}{c}\text { Sarcina } \\
\text { lutea }\end{array}$ & $\begin{array}{c}\text { compact, round; } \\
\text { convex or flat } \\
\text { profile }\end{array}$ & $\begin{array}{c}<1 ; \\
1-3\end{array}$ & $\begin{array}{c}\text { citric; produce } \\
\text { yellow pigment }\end{array}$ & smooth & $\begin{array}{c}\text { opaque, } \\
\text { brilliant, } \\
\text { moisture }\end{array}$ & $\begin{array}{c}\text { homogeneous; } \\
\text { soft texture }\end{array}$ & $\begin{array}{c}\text { smooth, } \\
\text { flat }\end{array}$ \\
\hline $\begin{array}{c}\text { Pseudomonas } \\
\text { fluorescens }\end{array}$ & $\begin{array}{c}\text { compact, round; } \\
\text { convex or flat } \\
\text { profile }\end{array}$ & $\begin{array}{c}<1 ; \\
\text { grayish (dirty white) } \\
\text { or without color; } \\
\text { produce green- } \\
\text { yellow fluorescent } \\
\text { pigment }\end{array}$ & smooth & $\begin{array}{c}\text { opaque, } \\
\text { brilliant, } \\
\text { moisture }\end{array}$ & $\begin{array}{c}\text { homogeneous; } \\
\text { soft texture }\end{array}$ & $\begin{array}{c}\text { smooth, } \\
\text { flat }\end{array}$ \\
\hline $\begin{array}{c}\text { Saccharomyces } \\
\text { cerevisiae }\end{array}$ & $\begin{array}{c}\text { round; colonies in the } \\
\text { deep have cross-like } \\
\text { borders, which burst } \\
\text { an agar; curved } \\
\text { profile }\end{array}$ & $1-5$ & gray-white & $\begin{array}{c}\text { hlightly } \\
\text { wrinkled }\end{array}$ & $\begin{array}{c}\text { sometimes matt } \\
\text { brilliant, }\end{array}$ & $\begin{array}{c}\text { homogeneous; } \\
\text { texture is oily } \\
\text { (pasty) and } \\
\text { thick }\end{array}$ & $\begin{array}{c}\text { sometimes } \\
\text { wavy }\end{array}$ \\
\hline
\end{tabular}

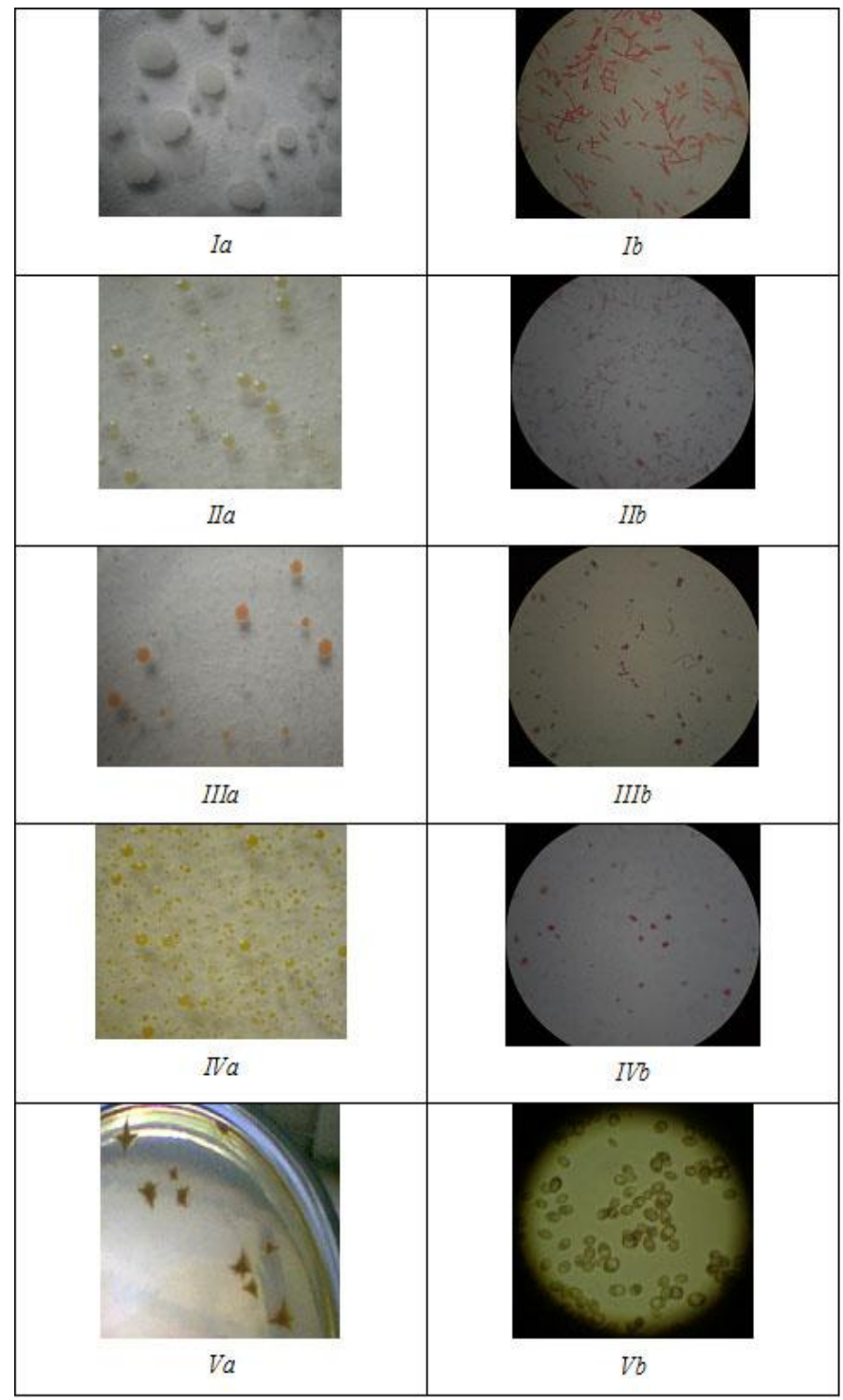

Fig. 1. Character of colonies growth in Petri dishes on a nutrient medium (a) and SEM images of microorganism cells (b) for Bacillus cereus (I); Sarcina lutea (II); Diplococcus (III); Pseudomonas fluorescens (IV) and Saccharomyces cerevisiae (V).

Magnification of $1200 \times(\mathrm{I}) ; 1500 \times(\mathrm{II}-\mathrm{IV})$ and $480 \times(\mathrm{V})$ 


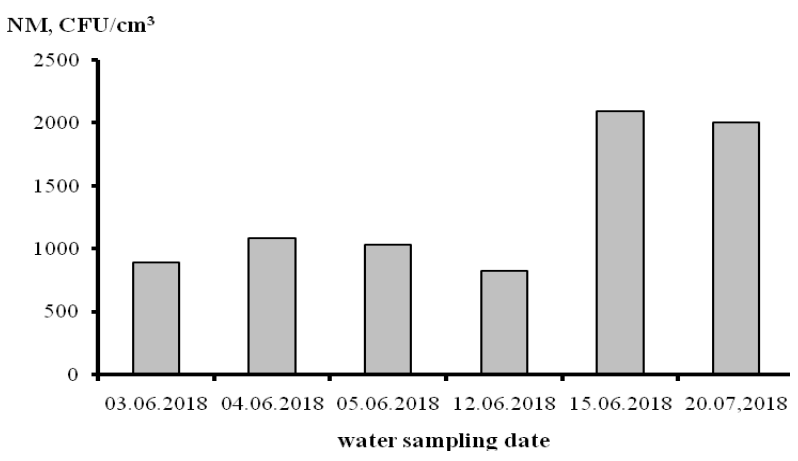

Fig. 2. Dynamics of $N M_{0}$ changes in the natural water Nol depending on the sampling date (sampling depth was $100 \mathrm{~mm}$ from the water surface)

\subsection{Destruction of Bacillus Cereus}

\section{Bacteria Type}

The effect of simultaneous gas/US action upon bacillary spore formation in the Bacillus cereus bacterium (Fig. 1, Ib) is shown in Fig. 3.

Consequently, one may compare Bacillus destruction within a cavitational field for different gases being bubbled into its dispersion and so determine the gaseous atmosphere in which this process is most effective: $\mathrm{Ar} / \mathrm{US}>\mathrm{O}_{2} / \mathrm{US}>\mathrm{He} / \mathrm{US}>\mathrm{CO}_{2} / \mathrm{US}$

It has been established that the most effective destruction process for the Bacillus bacteria occurs in the presence of argon in a cavitational field.

\subsection{Destruction of Pseudomonas}

\section{Fluorescens Bacteria Types}

Because bacillary Ps. fluorescens type bacteria (Fig. 1, Ilb), unlike Bacillus microbial cells, are unable to form spores, they were investigated for their response to gas/US treatment.

The $N M_{0}$ values in microbial dispersions were: $9.5 \cdot 10^{4} ; 9.7 \cdot 10^{3}$ and $1.8 \cdot 10^{3} \mathrm{CFU} / \mathrm{cm}^{3}$ for $\mathrm{O}_{2} / \mathrm{US}, \mathrm{CO}_{2} / \mathrm{US}$ and $\mathrm{Ar} / \mathrm{US}$, respectively. The process of water purification, which is subjected to a gas/US process over a twohour period, is shown in Fig. 4.

It should be noted that during the first stage of being subjected to He/US effect $(t=1800 \mathrm{~s})$ an increase in $N M$ was observed as a result of intensive disaggregation of microbial cells found in the effluent water, whilst active microorganism destruction $\left(t_{\mathrm{He} / \mathrm{US}}=1800-7200 \mathrm{~s}\right)$ was only observed at the second stage. Therefore, to determine $D_{d}$ values, the value of $N M_{\max }$ was considered instead of $N M_{0}$. For this reason, in this particular instance the comparison between the effect of helium and other gases in a cavitational field is inappropriate (this is not shown in the figure).

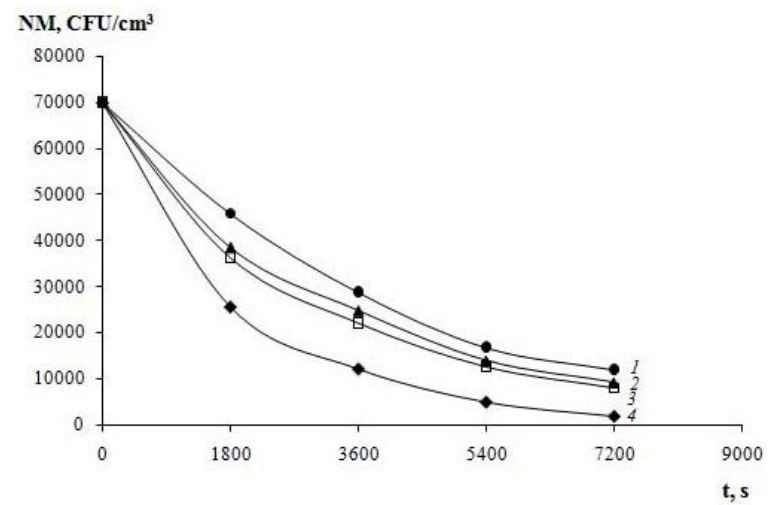

Fig. 3. Dependences of the relative number of microorganisms (Bacillus bacteria type) on the process time under the gas/US action: $\mathrm{CO}_{2} / \mathrm{US}(1), \mathrm{He} / \mathrm{US}(2), \mathrm{O}_{2} / \mathrm{US}(3), \mathrm{Ar} / \mathrm{US}(4)$. Conditions: $N M_{0}=7 \cdot 10^{4} \mathrm{CFU} / \mathrm{cm}^{3}, T=298 \pm 1 \mathrm{~K}$

The effective destruction order for Ps. fluorescens bacteria types for different gases being bubbled in a cavitational field is as follows:

$$
\mathrm{Ar} / \mathrm{US}>\mathrm{CO}_{2} / \mathrm{US}>\mathrm{O}_{2} / \mathrm{US}>\mathrm{He} / \mathrm{US}
$$

The most effective rate constants for the destruction of these bacteria $\left(3.96 \pm 0.02 \cdot 10^{-4} \mathrm{~s}^{-1}\right)$ was established for Ar/US action.

\subsection{Destruction of Diplococcus and}

\section{Sarcina Lutea Bacteria Types}

Although Diplococcus and Sarcina lutea bacteria types from the Coccaceae family are related to spherical microorganisms (Fig. 1, IIIb and Fig.1, IVb, respectively), they differ by size [22] and by numbers of connected cells (Diplococcus cells are connected in pairs, whilst Sarcina cells are in blocks).

The general effect of gas/US action on bacteria viability is shown in Fig. 5. According to calculated effective rate constants for microorganisms destruction, both Diplococcus $\left(k_{d}=3.29 \pm 0.03 \cdot 10^{-4} \mathrm{~s}^{-1}\right)$ and S.lutea $\left(k_{d}=\right.$ $\left.=5.95 \pm 0.07 \cdot 10^{-4} \mathrm{~s}^{-1}\right)$ are destroyed most readily in the presence of argon rather than in helium. The value of $k_{d}$ is less by 0.52 and 0.55 times under He/US for Diplococcus and S.lutea, respectively.

Comparing the efficiency of the process for monocultures, more active destruction of Sarcina (both in argon and in helium) is observed, which may be related to its significantly larger cell size compared to that of Diplococci ( 3.5 times) [22]. Thus, the destruction of Diplococcus and S.lutea under cavitation conditions has been shown to occur most effectively in argon. $D_{d}$ is approximately twice higher under Ar/US condition than for $\mathrm{He} / \mathrm{US}$ as shown by the curves of the relative number of microorganisms in the figure. The influence of oxygen and carbon dioxide under cavitation conditions is not presented in the figure, since under these conditions processes of disaggregation of microbial cell clusters were observed and such processes were described in [23]. 


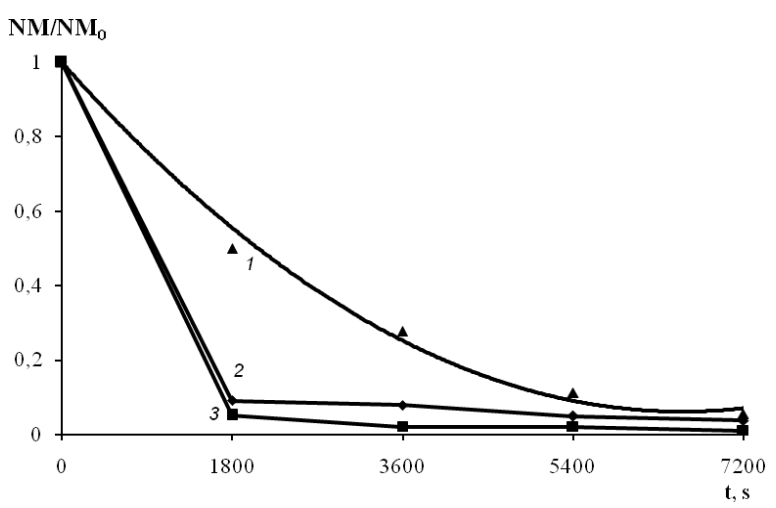

Fig. 4. Dependences of the relative number of microorganisms (Ps.fluorescens bacteria type) on the process time under the gas/US action: $\mathrm{O}_{2} / \mathrm{US}(1), \mathrm{CO}_{2} / \mathrm{US}(2)$,

$\mathrm{Ar} / \mathrm{US}$ (3). Conditions: $N M_{0}=9.5 \cdot 10^{4}$ for $\mathrm{O}_{2} / \mathrm{US} ; N M_{0}=9.7 \cdot 10^{3}$ for $\mathrm{CO}_{2} / \mathrm{US} ; N M_{0}=1.8 \cdot 10^{3}$ for $\mathrm{Ar} / \mathrm{US} ; T=298 \pm 1 \mathrm{~K}$

\subsection{Destruction of the Saccharomyces Cerevisiae Yeast}

According to Fig. 6, the efficiency of Sacch. cerevisiae destruction (Fig. 1, Vb) when subjected to inert gas bubbling for $t_{\mathrm{ga} / \mathrm{US}}=5400-7200 \mathrm{~s}$ remains practically unchanged, compared to that for oxygen and carbon dioxide. The yeast suspension was $>98 \%$ after one hour of the process duration, which confirms the previous results [14]. The number of yeast cells per $1 \mathrm{~cm}^{3}$ did not exceed 100 cells after $t_{\mathrm{gas} / \mathrm{US}}=3600 \mathrm{~s}$. This mean that in accordance with acceptable microbiological parameters the investigated water meets fully with drinking water requirements.

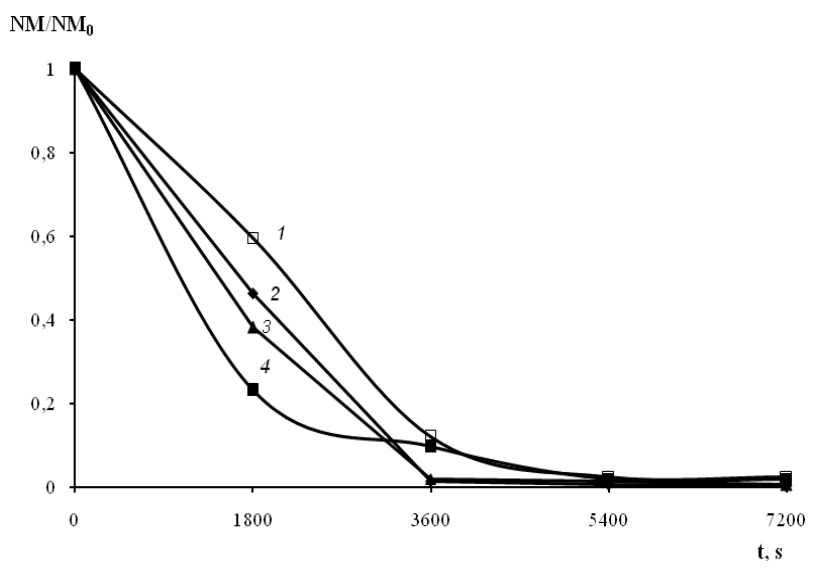

Fig. 6. Dependences of the relative number of yeasts (Sacch. cerevisiae) on the process time under the gas/US action: $\mathrm{He} / \mathrm{US}(1), \mathrm{O}_{2} / \mathrm{US}(2), \mathrm{Ar} / \mathrm{US}(3), \mathrm{CO}_{2} / \mathrm{US}$ (4). Conditions: $N M_{0}=(4.2-5.2) \cdot 10^{3} \mathrm{CFU} / \mathrm{cm}^{3}$ for $\mathrm{He} / \mathrm{US}$ and $\mathrm{CO}_{2} / \mathrm{US}$; $\mathrm{NM}_{0}=(1.9-2.07) \cdot 10^{4} \mathrm{CFU} / \mathrm{cm}^{3}$ for $\mathrm{O}_{2} / \mathrm{US}$ and $\mathrm{Ar} / \mathrm{US}$; $T=298 \pm 1 \mathrm{~K}$

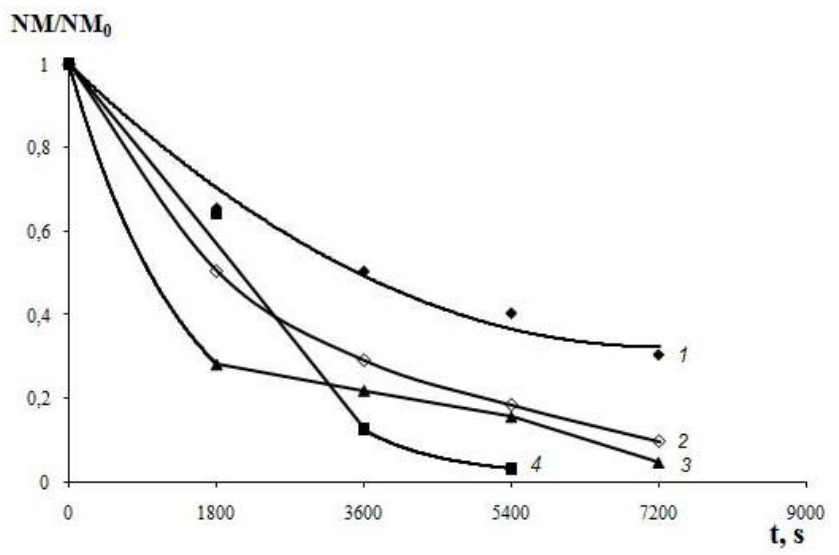

Fig. 5. Dependences of the relative number of microorganisms (Diplococcus $(1,2)$ and S.lutea $(3,4)$ bacteria types) on the process time under the gas/US action: $\mathrm{He} / \mathrm{US}(1,3)$ and Ar/US $(2,4)$. Conditions: $N M_{0}=1.1 \cdot 10^{5} \mathrm{CFU} / \mathrm{cm}^{3}(1,2)$ and $N M_{0}=6.4 \cdot 10^{3} \mathrm{CFU} / \mathrm{cm}^{3}(3,4) ; T=298 \pm 1 \mathrm{~K}$

The destruction effectiveness order for Sacch. cerevisiae when subjected to various gas/US combinations is as follows: $\mathrm{Ar} / \mathrm{US}>\mathrm{He} / \mathrm{US}>\mathrm{CO}_{2} / \mathrm{US}>\mathrm{O}_{2} / \mathrm{US}$.

As a result, the yeast suspension was almost entirely disinfected under cavitation conditions for various bubbled gases in a relatively short time period compared to that for microbial dispersions. It should be noted that the unicellular yeast type fungi studied (eukaryotes) differ significantly in their morphology from the prokaryotes in this study. Yeast cells, unlike bacterial ones, although characterized by stronger membranes, are almost 10 times larger [22]. This may have a direct bearing upon the destruction effect experienced under cavitation conditions.

\section{Conclusions}

This study has yielded the following results:

The destruction of Diplococcus, S.lutea, B.cereus, Ps.fluorescens bacteria types and the Sacch.cerevisiae yeast under cavitation action depends on the nature of the bubbled gas. The relative destruction efficiency for cells subjected to gas/US shows the greatest water disinfection efficiency for argon compared to helium, oxygen and carbon dioxide.

Regardless of the types of microorganism studied, their morphology, and their concentration per unit volume of dispersion, the highest effectiveness of microorganism destruction in the aqueous medium was observed under the simultaneous action of argon and cavitation.

\section{References}

[1] Prado M., Borea L., Cesaro A. et al.: Int. Biodeter. Biodegr., 2017, 119, 577. https://doi.org/10.1016/j.ibiod.2016.10.044 
[2] Fei G., Lizhong Z., Jing W.: Desalination, 2008, 225, 156. https://doi.org/10.1016/j.desal.2007.03.016

[3] Zhou X., Zhao J., Li Z. et al.: Ultrason. Sonochem., 2016, 28, 376. https://doi.org/10.1016/j.ultsonch.2015.08.017

[4] Cameron M., Lynn D., Britz T.: Ultrason. Sonochem., 2008, 15, 960. https://doi.org/10.1016/j.ultsonch.2008.02.012

[5] Badve M., Bhagat M., Pandit A.: Sep. Purif. Technol., 2015, 151, 31. https://doi.org/10.1016/j.seppur.2015.07.020

[6] Drakopoulou S., Terzakis S., Fountoulakis M. et al.: Ultrason. Sonochem., 2009, 16, 629.

https://doi.org/10.1016/j.ultsonch.2008.11.011

[7] Sun X., Park J., Kim H. et al.: Ultrason. Sonochem., 2018, 49,

13. https://doi.org/10.1016/j.ultsonch.2018.02.039

[8] Stamper D., Holm E., Brizzolara R.: J. Environ. Eng. Sci., 2008,

7, 139. https://doi.org/10.1139/S07-044

[9] You J., Guo Y., Guo R. et al.: Chem. Eng. J., 2019, 373, 624. https://doi.org/10.1016/j.cej.2019.05.071

[10] Koval I., Starchevskyy V., Shevchuk L.: $12^{\text {th }}$ Meeting of the European Society of Sonochemistry, Greece, Crete 2010, 106.

[11] Koval I., Shevchuk L., Starchevskyy V.: Chem. Eng. Transact., 2011, 24, 1315. https://doi.org/10.3303/CET1124220

[12] Starchevskyy V., Koval I., Shevchuk L. et al.: $11^{\text {th }}$ Meeting of the European Society of Sonochemistry, France, La Grande-Motte 2008, 159.

[13] Koval I., KislenkoV., Shevchuk L. et al.: Chem. Chem. Technol., 2011, 5, 463. https://doi.org/10.23939/chcht05.04.463 [14] Sun X., Kang C., Park J. et al.: Exp. Therm. Fluid Sci., 2018, 99, 200. https://doi.org/10.1016/j.expthermflusci.2018.02.034 [15] Jain P., Bhandari V., Balapure K. et al.: J. Environ. Manage., 2019, 242, 210. https://doi.org/10.1016/j.jenvman.2019.04.057 [16] Xiaoge W., Eadaoin M., Mason J.: $11^{\text {th }}$ Meeting of the European Society of Sonochemistry, France, La Grande-Motte $2012,115$.

[17] Eadaoin J., Xiaoge W., Mason J.: $11^{\text {th }}$ Meeting of the European Society of Sonochemistry, France, La Grande-Motte 2012, 47.
[18] Nykypanchuk M., Hrynchuk Yu. et al.: Chem. Chem. Technol., 2013, 7, 467. https://doi.org/10.23939/chcht07.04.467

[19] Melnyk Y., Reutskyy V., Starchevskyy V. et al.: Chem. Chem. Technol., 2014, 8, 177. https://doi.org/10.23939/chcht08.02.177 [20] Koval I., Falyk T.: $15^{\text {th }}$ Int. Scientific-Practical Conference "Resources of Natural Waters in Carpathian Region", Ukraine, Lviv 2016, 92.

[21] Koval I., Shevchuk L.: $5^{\text {th }}$ Int.1 Youth Science Forum "Litteris et Artibus", Ukraine, Lviv 2015, 372.

[22] Koval I.: Int. Symposium "The Environment and the Industry", Romania, Bucharest 2018, 362.

https://doi.org/10.21698/simi.2018.fp43

[23] Koval I.: Int. Symposium "The Environment and the Industry", Romania, Bucharest 2017, 56.

https://doi.org/10.21698/simi.2017.0007

Received: April 7, 2019/Revised: April 20, $2019 /$ Accepted: July 12, 2019

\section{ВСТАНОВЛЕННЯ ЕФЕКТИВНОӤ ПРИРОДИ ГАЗУ НА РУЙНУВАННЯ РІЗНИХ МІКРООРГАНІЗМІВ ПІД ДІЄЮ КАВІТАЦІї}

Анотація. Досліджено знезараження води від бактерій poдy Diplococcus, S.lutea, B.cereus, Ps.fluorescens ma дріжджів Sacch.cerevisiae за одночасної дї газ/УЗ як мікроорганізми, які були визначені в природних та стічних водах в домінуючій кількості. Встановлені відносні ряди ефективного руйнування клітин під дією газ/УЗ. Найбільша ефективність знищення мікроорганізмів було досягнуто під дією $\mathrm{Ar} / \mathrm{V} 3$, порівняно 3 $\mathrm{He} / \mathrm{Y} 3, \mathrm{CO}_{2} / \mathrm{Y} 3$ і $\mathrm{O}_{2} / \mathrm{У} 3$ щуо пояснюється властивостями газу, здатними впливати на сонохімічну активність.

Ключові слова: кавітація, газ, вода, мікроорганізми, руйнування. 